\title{
Facebook usage for Seeking News and Information by Urban Journalists in Pakistan
}

\author{
Bashir Memon and Liaquat Ali Umrani \\ Department of Media and Communication Studies, University of Sindh, Jamshoro, Sindh, Pakistan; \\ bashir.memon@usindh.edu.pk, liaquat.umrani@usindh.edu.pk
}

\begin{abstract}
Objectives: This study aimed to know that how communication professionals specifically journalists residing in urban areas use Facebook, a social media platform, for their professional activities. Method: The data for this study was collected by doing a cross-sectional quantitative survey with the help of pre-designed close-ended questionnaire that was distributed among the urban journalists in Sindh province, Pakistan in a face to face situation. Then the data was analyzed in SPSS statistical software. Findings: The findings have been presented in tables and then described and analyzed to know the Facebook usage patterns of the sampled urban journalists. In this way, it was observed that the journalists used Facebook for their professional activities i.e. they used Facebook to receive and share news and information. Novelty: Facebook that was made to interweave social networking is also used for journalistic professional activities.
\end{abstract}

Keywords: Facebook, Information, Journalists, News, Social Media

\section{Introduction}

Change in technologies, the information seeking methods as well change1. In this way, among other technological developments, social media, due to its interactive nature, is as well popular in the world.

Unlike other users, journalists are not only using social media to build relationships with online communities but also for reasons which are advantageous to their work ${ }^{2}$. Additionally, it is observed that among Social Networking Sites (SNSs) Facebook appears to be a comparatively better SNS for journalists to find, share and promote news stories to survive in a competitive media market.

Hence, news-workers are tending to Facebook and other SNSs to seek information. However, due to the notion of speed involved in journalism and lack of resources available to journalists they have to conduct research for detailed background information; however, that is often the most time-taking factor in writing a news story. Therefore, journalists prefer speedy network like Facebook to find and share news stories urgently to cater information needs of the audiences and media organisations. In this relation, Arceneux and Weiss (2010) concluded that journalists could gather and disseminate information at near-instantaneous speed by using social media tools ${ }^{3}$.

According to ${ }^{4}$ journalists use social media such as Twitter and Facebook to gather newsworthy information and seek out potential interviewees.

Often during searching a story, connections provided by others take to the reporting journalist to an important source. Since, Facebook is generating and maintaining connections, the possibility that someone within a journalist's clique of cyber friends may be able to attach a reporter to a source would look like to be great. Added to that a journalist's (often secret) network of sources has always been one of his/her most critical professional assets ${ }^{5}$. It is usually monitored that many journalists develop news story ideas by going through personal Facebook wall where online social contacts share different stories of their interests.

Many news-workers now use Facebook and other SNSs to help them in their story finding and investigation as contributed. Background information is easily available on such kind of sites ${ }^{6}$. Moreover, due to its easy use Facebook becomes user friendly, and the information could be easily accessed by messaging to fellow journalists and story sources. Further, adds that the casual com- 
municative character of Facebook may turn it easier to approach a source; either the Facebook friend or someone they are acquainted with ${ }^{7}$.

\section{Finding News and Information on Facebook}

$\mathrm{In}^{8}$ while conducting study regarding public relations and strategies found that most of the journalists seek stories from social media such as Facebook. It has also provided a new approach to increase the source of information to access the news and connectivity with other information about different issues and problems of the society.

According to the findings of Pew Research Centre's Journalism Project (2015) getting news on Facebook is an incidental experience. 78\% of the Facebook users commonly find news on Facebook despite the fact that their primary motives behind Facebook usage were primarily not for news. Level of engagement with the news also plays an essential role in social media news experience 9 .

$\mathrm{In}^{10}$ found in their study that social contacts and engaging with people as a source of information are considered the leading indicators of information searching behaviour. Moreover, to the difference between users who primarily use Facebook to search information and those who use Facebook for other purpose is dependent on their demographic and usage behaviour differences.

\section{Sharing news and information on Facebook}

In $^{11}$ define term "news sharing" as a particular type of information sharing instead of describing it as a general activity of information sharing. Thus, news sharing involves the sharing of particular content and not applied to the collective activity of sharing.

In $^{12,13}$ found in their study that ordinary users were more possible to share such stories which support their idea; however, they do not share those stories which come in the contradiction to their mentality have a different and opposite viewpoint in this regard; as they concluded that users often share those news stories that differ from their thinking.

Furthermore, focused on the interest value of information as a dependent factor for news sharing activity. The worth of news concerning the interest on one's social network determines the level of sharing ${ }^{14}$. $\operatorname{In}^{15}$ indicated that besides the interest the worth of the substance of news story, quality of the news source also plays a vital role in sharing behaviour of social media users. Additionally, the trust in the sources of news may affect the news sharing activity.

$\mathrm{In}^{16}$ put that environmental and outside feature may influence news sharing activities of the journalists. They more found that during periods of heightened political bustle, public affairs substance (featuring politics, government, or economics) is shared more often compare with non-public affairs content (featuring entertainment, sports, or crime).

Thus this study was conducted upon the usage of Facebook for getting news and information by urban journalists in Sindh province, Pakistan.

\subsection{Hypotheses}

1. Unmarried journalists use Facebook more than married ones for professional activities.

2. Younger age journalists use Facebook more than older age for professional activities.

3. Less educated journalists use Facebook more than highly educated for professional activities.

4. Urdu speaking journalists use Facebook more than Sindh speaking journalists.

5. News reporting journalists use Facebook more than news editing journalists.

6. Journalists working in Karachi division use Facebook more than journalists working in Hyderabad District.

\section{Methodology}

\subsection{Research Design}

For data collection a cross-sectional survey was conducted. As using a survey technique in communication research has become a common practice. Moreover ${ }^{17}$ put that survey has central importance in communication research. Thus, researcher personally visited newspaper organisations, TV channels, news agency offices and press clubs to meet journalists and getting filled questionnaires in a face to face situation, as any query about the questionnaire may be answered on the spot and valid responses could be obtain.

\subsection{Population and Sampling}

The focussed population of this study was working journalists in urban section of Sindh province, Pakistan. The 
selection of the participants was those journalists who were practically involved in reporting, editing, writing and other journalism related activities and who were working in Karachi division and Hyderabad district of Sindh province. Moreover, they were employed in print, electronic and online media organisations, and news agencies either privately owned or state-run.

Whereas, for sampling the researcher decided to select a sample by applying a purposive sampling procedure; as the complete list of the journalists working in Karachi division and Hyderabad district was not available. Hence, this situation caused a starting point for the researcher to use a purposive sampling method. As in this connection put Singleton \& Straits (1999) that "In situations that preclude random selection, purposive sampling is an acceptable alternative ${ }^{18}$. Finally, in this study total 374 journalists participated in the survey.

\subsection{Data collection and Analysis}

The researcher personally visited all press clubs and media organisations available in Karachi division and Hyderabad district for conducting survey. Hence, for primary data collection, a fully structured questionnaire was designed. The questionnaire was mostly consisted of close-ended questions. Whereas, the secondary data was obtained from various research articles, theses, and books related to the field of the research. Whereas, for data analysis firstly data was coded in SPSS (Statistical Package for Social Science) software and then it was analysed and measured with relevant statistical tests.

\subsection{Findings}

\subsubsection{Demographic Profile of the Journalists}

The Table 1 shows that the part of higher than fourfifths $(88.8 \%)$ of the respondents were male. However, the other proportion of $11.2 \%$ was female. Hence, it indicated that the majority of the news-workers in this survey were male. Moreover, subject to marital status the proportion measuring almost three fifths (59.7\%) journalists was married. However, the remaining part of $40.3 \%$ mentioned themselves as unmarried. Thus it revealed that the majority proportion of the journalists was married. In the regard of age, it was observed that the proportion of nearly three fifths (57.3\%) were between 25 to 40 years in age. Whereas, the second proportion of about one quarter $(23.7 \%)$ were up to 25 years old. And the remaining pro- portion calculated as almost one fifth (19.0\%) was more than 40 years old. Thus, it concluded that the majority proportion of the news-workers surveyed in this study belonged to young age group.

Table 1. Composition of the urban journalists by demographic variables

\begin{tabular}{|c|c|c|}
\hline Variable & Frequency & Percentage (\%) \\
\hline \multicolumn{3}{|l|}{ Gender } \\
\hline Male & 326 & $(88.8)$ \\
\hline Female & 41 & $(11.2)$ \\
\hline \multicolumn{3}{|l|}{ Marital status } \\
\hline Married & 216 & $(59.7)$ \\
\hline Unmarried & 146 & $(40.3)$ \\
\hline \multicolumn{3}{|l|}{ Age } \\
\hline Up to 25 years & 66 & $(23.7)$ \\
\hline $\begin{array}{l}\text { Between } 25 \text { t0 } 40 \\
\text { years }\end{array}$ & 160 & $(57.3)$ \\
\hline Above 40 years & 53 & $(19.0)$ \\
\hline \multicolumn{3}{|l|}{ Mother language } \\
\hline Sindhi & 256 & $(69.9)$ \\
\hline Urdu & 110 & $(30.1)$ \\
\hline \multicolumn{3}{|l|}{ Religious identity } \\
\hline Muslim & 338 & $(92.6)$ \\
\hline Non-Muslim & 27 & $(7.4)$ \\
\hline \multicolumn{3}{|l|}{ Education } \\
\hline $\begin{array}{l}\text { Intermediate and } \\
\text { less }\end{array}$ & 44 & $(11.8)$ \\
\hline Bachelor's degree & 135 & $(36.3)$ \\
\hline Master's and above & 188 & $(50.5)$ \\
\hline \multicolumn{3}{|l|}{ Monthly income } \\
\hline $\begin{array}{l}\text { Up t0 } 15000 \mathrm{PK} \\
\text { Rupees }\end{array}$ & 103 & $(27.7)$ \\
\hline $\begin{array}{l}\text { More than } 15000 \mathrm{PK} \\
\text { Rs. }\end{array}$ & 154 & $(41.4)$ \\
\hline No answer & 110 & $(29.6)$ \\
\hline \multicolumn{3}{|l|}{ Working city } \\
\hline Hyderabad & 162 & $(44.1)$ \\
\hline Karachi & 205 & $(55.9)$ \\
\hline
\end{tabular}

Added to that when the journalists were asked about their mother language then the proportion which stood more than two-thirds (69.9\%) was Sindhi speaking. While the other proportion of less than one third (30.1\%) was Urdu speaking. Therefore, it concluded that the majority of the sampled journalists were Sindhi speaking. In the regard of 
religion the proportion of higher than four-fifths (92.6\%) of the journalists were Muslims. While the remaining proportion measured as less than one-tenth $(7.4 \%)$ were non-Muslims. Therefore, it surfaced that the majority journalists were Muslim.

Academically it was observed that the proportion of higher than four-fifths (86.8\%) had a university degree, while the remaining proportion calculated as $13.3 \%$ sought their final degree from colleges and schools. Hence, it concluded that the majority proportion of the surveyed journalists in this study had university degree. Moreover, regarding income level of the surveyed journalists it mentioned that the proportion measuring more than a quarter $(27.7 \%)$ earned monthly up till fifteen thousand $(150000 /=)$ PK rupees. While the proportion of higher than two fifths (41.4\%) said that they earned more than $15000 /=$ PK rupees from journalism profession. However, the remaining proportion of higher than a quarter $(29.6 \%)$ did not answer to this question. Finally, about the working city, it was observed that the proportion of higher than fifty percentage (55.9\%) news-workers was working in Karachi. Whereas, the other proportion

Table 2. Work profile of the urban journalists in Sindh province

\begin{tabular}{|l|l|l|}
\hline Variable & Frequency & Percentage (\%) \\
\hline Job title & \multicolumn{2}{l|}{} \\
\hline News editing & 202 & $(54.3)$ \\
\hline News reporting & 106 & $(28.5)$ \\
\hline Other & 60 & $(16.1)$ \\
\hline Media organisation & \multicolumn{2}{|l|}{} \\
\hline Newspaper & 128 & $(34.4)$ \\
\hline Radio & 13 & $(3.5)$ \\
\hline Magazine & 11 & $(3.0)$ \\
\hline News agency & 35 & $(9.4)$ \\
\hline TV channel & 188 & $(50.5)$ \\
\hline Online sites & 39 & $(10.5)$ \\
\hline Media organisation language & \\
\hline Sindhi & 237 & $(63.7)$ \\
\hline Urdu & 156 & $(41.9)$ \\
\hline English & 47 & $(12.6)$ \\
\hline Work experience & & $(33.8)$ \\
\hline Cub journalist & 79 & $(27.8)$ \\
\hline Junior journalist & 65 & $(38.5)$ \\
\hline Senior journalist & 90 & \\
\hline
\end{tabular}

of higher than two fifths (44.1\%) worked in Hyderabad city. Thus, it concluded that the majority of the journalists surveyed in this study worked in Karachi.

\subsection{Work Profile of the Journalists}

As per Table 2 about the working profile of the urban journalists it surfaced about the job title of the urban new-workers that the segment of more than fifty per cent (54.3\%) had their job title which referred to news editing group. Whereas, against it, the other proportion that measured over than one quarter (28.5\%) were involved in news reporting. While the remaining proportion of $16.1 \%$ expressed that they worked for other categories of journalistic work such as director news assistant director news. Thus, it was put that the majority of the surveyed news-workers were working in news editing job.

Similarly the respondents were also inquired about the type of media organisation they were working for. In this regard, the proportion that was slightly over than one third (34.4\%) mentioned that they worked in newspaper organisations. Moreover, the proportion of $6.5 \%$ worked in radio (3.5\%) and magazine (3.0\%) organisations. While the proportion of nearly one-tenth $(9.4 \%)$ revealed that they worked in news agency organisations. The proportion of slightly higher than half (50.5\%) of the journalists worked in television stations. Lastly, the proportion of bit over than one tenth (10.5\%) of them worked for online media. Thus, it was concluded that the majority proportion of the journalists surveyed worked for television media.

The data regarding language of the media organisations showed that the proportion of nearly two-thirds (63.7\%) of the journalists were employed in Sindhi language media organisations. However, the other proportion of higher than two fifths (41.9\%) of the journalists worked in Urdu media organisations. Additionally, the proportion of higher than one tenth (12.6\%) said that they worked in English language organisations. Thus, it was deduced that the majority of the surveyed journalists were employed in Sindhi language media organisations.

The findings regarding the work experience of the journalists mentioned that the proportion of little over than one third (33.8\%) were cub journalists. Added, the proportion of higher than one quarter $(27.8 \%)$ was junior journalists. However, the remaining segment of about two fifths $(38.5 \%)$ was senior journalists. Hence, it concluded that the majority of the surveyed journalists were senior by professional experience. 


\subsection{Facebook usage by Urban Journalists for} News and Information

Data in Table 3 show the frequency level of using Facebook by urban journalists of Sindh for news and information activities. The results indicated that the first highest activity of the journalists while using Facebook is 'Finding news story' $(\mathrm{M}=3.08)(\mathrm{SD}=.911)$. Whereas, the second highest professional activity on Facebook by the urban journalists was 'getting story ideas' $(\mathrm{M}=2.87)$ $(\mathrm{SD}=.876)$. In this way, the urban journalists in Sindh province revealed that they use Facebook for getting story ideas. In this way, this result indicates that urban journalists find news stories on Facebook very critically as they not only get updated with fresh information but also get ideas for more news stories as well. Moreover, the professional activity of sharing news stories $(\mathrm{M}=2.81)(\mathrm{SD}=$ .861 ) is the third most frequent activity by the urban journalists on Facebook. Finally, however among all above said professional activities on Facebook the least favourite activities of the urban journalists on Facebook was 'saving news stories' $(\mathrm{M}=2.49)(\mathrm{SD}=.981)$ and 'following news stories' $(\mathrm{M}=2.59)(\mathrm{SD}=.914)$.

\subsection{Facebook usage for News and Information and Demographic Variables}

Findings in Table 4 present results related to journalists' Facebook usage activities for news and information

Table 3. Facebook usage by journalists for news and information

\begin{tabular}{|l|l|l|l|l|}
\hline $\begin{array}{l}\text { Facebook usage } \\
\text { for news and } \\
\text { information }\end{array}$ & Mean & Mode & Median & SD \\
\hline $\begin{array}{l}\text { Finding news and } \\
\text { information on } \\
\text { Facebook }\end{array}$ & 3.08 & 3 & 3.00 & .911 \\
\hline $\begin{array}{l}\text { Getting news story } \\
\text { ideas from Facebook }\end{array}$ & 2.87 & 3 & 3.00 & .876 \\
\hline $\begin{array}{l}\text { Following stories } \\
\text { shared on Facebook }\end{array}$ & 2.59 & 3 & 3.00 & .914 \\
\hline $\begin{array}{l}\text { Saving Facebook news } \\
\text { and information }\end{array}$ & 2.49 & 3 & 3.00 & .981 \\
\hline $\begin{array}{l}\text { Sharing news and } \\
\text { information on } \\
\text { Facebook }\end{array}$ & 2.81 & 3 & 3.00 & .861 \\
\hline
\end{tabular}

Note: Higher mean score equals greater level professional activity. The scale ranges from $4=$ most frequently, $3=$ frequently, $2=$ less frequently, $1=$ not at all. subject to marital status of the journalists. In this regard, it was found first about the activity of finding news and information on Facebook that on average unmarried journalists $(M=3.18)$ used Facebook more than married journalists $(\mathrm{M}=3.01),(\mathrm{t}=-1.796, \mathrm{p}=.073)$ for finding news and information. Second in the context of getting news story ideas from Facebook the data showed that on average unmarried journalists $(\mathrm{M}=2.92)$ used Facebook more than married journalists $(\mathrm{M}=2.83),(\mathrm{t}=-1.042, \mathrm{p}=.298)$ for getting news story ideas. Third regarding following stories shared on Facebook the results indicated that on average the unmarried journalists $(M=2.72)$ used Facebook more than married journalists $(M=2.50),(t=-2.250, p=.025)$ for following the story shared on Facebook. About the fourth activity that is saving Facebook news the result showed that on average the unmarried journalists $(\mathrm{M}=2.57)$ used more Facebook to save stories than married journalists $(\mathrm{M}=2.43),(\mathrm{t}=-1.356, \mathrm{p}=.176)$ for saving Facebook news and information. Finally, the results related to the activity of sharing news on Facebook indicated that on average unmarried journalists $(\mathrm{M}=2.86)$ used Facebook more for sharing news stories than married journalists $(\mathrm{M}=2.87)$, $(\mathrm{t}=-.846, \mathrm{p}=.398)$. Therefore, overall it was concluded that in the context of marital status those journalists who were unmarried on average used Facebook more for all news and information activities mentioned above.

Data in Table 5 presents findings related to journalists' Facebook usage for news and information and age of the news-workers. In this way, first, about the activity of finding news and information on Facebook it surfaced that on average those journalists whose age was thirty years old $(\mathrm{M}=3.20)$ used Facebook more heavily than those whose age was above thirty years $(\mathrm{M}=2.88),(\mathrm{t}=2.887, \mathrm{p}=.004)$. Second, in the context of getting news story ideas from Facebook information the data mentioned that on average those journalists who were up to thirty years old $(M=2.96)$ used Facebook higher than those whose age was above thirty years $(\mathrm{M}=2.73),(\mathrm{t}=2.169, \mathrm{p}=.031)$. Third, in the regard of following news stories shared on Facebook the data mentioned that on average those whose age was up to thirty years $(\mathrm{M}=2.70)$ used Facebook more than those whose age was above thirty years $(\mathrm{M}=2.41),(\mathrm{t}=2.770$, $\mathrm{p}=.006$ ). Fourth, subject to saving Facebook information, the data indicated that on average those journalists whose age was up to thirty years $(M=2.56)$ used Facebook more than those whose age was above thirty years $(\mathrm{M}=2.33)$, $(t=1.995, p=.047)$. Finally, the results related to the activity of sharing news on Facebook pointed out that on aver- 
Table 4. Facebook usage activities for news/ information and marital status

\begin{tabular}{|l|l|l|l|l|}
\hline \multirow{2}{*}{$\begin{array}{l}\text { Facebook usage activities for news and } \\
\text { information }\end{array}$} & Marital status & \multirow{2}{*}{ T-test } \\
\cline { 2 - 4 } & Married Mean & Unmarried Mean & \multirow{2}{*}{ P-value } \\
\hline Finding news and information on Facebook & 3.01 & 3.18 & -1.796 & .073 \\
\hline Getting news story ideas from Facebook & 2.83 & 2.92 & -1.042 & .298 \\
\hline Following stories shared on Facebook & 2.50 & 2.72 & -2.250 & .025 \\
\hline Saving Facebook news and information & 2.43 & 2.57 & -1.356 & .176 \\
\hline Sharing news and information on Facebook & 2.78 & 2.86 & -.846 & .398 \\
\hline
\end{tabular}

Note: Higher mean score equals greater level professional activity. The scale ranges from $4=$ most frequently, $3=$ frequently, $2=$ less frequently, $1=$ not at all.

age those journalists whose age was up to thirty years $(\mathrm{M}=2.86)$ used Facebook more than those whose age was above thirty years $(\mathrm{M}=2.65),(\mathrm{t}=1.959, \mathrm{p}=.051)$. Hence, it was deduced that subject to age, those news-workers who were up to thirty years age used Facebook more for all news and information activities mentioned above.

Data in Table 6 presents findings related to journalists' Facebook usage activities for news and information and the education of the surveyed journalists. Thus first, about the activity of finding news and information on Facebook it revealed that on average those who were educated up to a bachelor degree $(M=3.09)$ used
Facebook more than those who had a master degree or above ( $M=3.06),(t=.267, p=.789)$. Second, in the context of getting news story ideas from Facebook information the data showed that on average those who were educated up to a bachelor degree $(\mathrm{M}=2.94)$ used Facebook more than those who had a master degree or above $(M=2.80)$, $(\mathrm{t}=1.474, \mathrm{p}=.141)$. Thirdly subject to following news stories shared on Facebook the data showed that on average those who were educated up to a bachelor degree $(\mathrm{M}=2.72)$ used Facebook more than those journalists who were master degree holders or above $(\mathrm{M}=2.47),(\mathrm{t}=2.655$, $\mathrm{p}=.008)$. Fourth regarding saving Facebook information,

Table 5. Facebook usage activities for news/ information and age

\begin{tabular}{|l|l|l|l|l|}
\hline \multirow{2}{*}{$\begin{array}{l}\text { Facebook usage activities for news and } \\
\text { information }\end{array}$} & Age in years & \multirow{2}{*}{ T-test } & \multirow{2}{*}{ P-value } \\
\cline { 2 - 5 } & Up to 30 Mean & Above 30 Mean & & 2.887 \\
\hline Finding news and information on Facebook & 3.20 & 2.88 & 2.169 & .004 \\
\hline Getting news story ideas from Facebook & 2.96 & 2.73 & 2.770 & .006 \\
\hline Following stories shared on Facebook & 2.70 & 2.41 & 1.995 & .047 \\
\hline Saving Facebook news and information & 2.56 & 2.33 & 1.959 & .051 \\
\hline Sharing news and information on Facebook & 2.86 & 2.65 & & \\
\hline
\end{tabular}

Note: Higher mean score equals greater level professional activity. The scale ranges from $4=$ most frequently, $3=$ frequently, $2=$ less frequently, $1=$ not at all.

Table 6. Facebook usage activities for news/information and education

\begin{tabular}{|l|l|l|l|l|}
\hline \multirow{2}{*}{$\begin{array}{l}\text { Facebook usage activities for news and } \\
\text { information }\end{array}$} & \multicolumn{2}{|l|}{ Education } & \multirow{2}{*}{ T-test } \\
\cline { 2 - 4 } & Till bachelor Mean & Master \& above Mean & & .267 \\
\hline Finding news and information on Facebook & 3.09 & 3.06 & .789 \\
\hline Getting news stories ideas from Facebook & 2.94 & 2.80 & 2.47 & .474 \\
\hline Following stories shared on Facebook & 2.72 & 2.33 & 2.655 & .008 \\
\hline Saving Facebook news and information & 2.66 & 2.74 & 3.251 & .001 \\
\hline Sharing news and information on Facebook & 2.89 & 1.720 & .086 \\
\hline
\end{tabular}

Note: Higher mean score equals greater level professional activity. The scale ranges from $4=$ most frequently, $3=$ frequently, $2=$ less frequently, 1 = 'not at all'. 
Table 7. Facebook usage activities for news/information and mother language

\begin{tabular}{|l|l|l|l|l|}
\hline \multirow{2}{*}{ Facebook usage activities for news and information } & \multicolumn{2}{|}{ Mother language } & \multirow{2}{*}{ T-test } & \multirow{2}{*}{ P-value } \\
\cline { 2 - 5 } & Sindhi Mean & Urdu Mean & & \\
\hline Finding news and information on Facebook & 3.16 & 2.88 & 2.647 & .015 \\
\hline Getting news story ideas from Facebook & 2.96 & 2.65 & 2.839 & .005 \\
\hline Following stories shared on Facebook & 2.65 & 2.45 & 1.982 & .048 \\
\hline Saving Facebook news and information & 2.63 & 2.15 & 4.367 & .000 \\
\hline Sharing news and information on Facebook & 2.88 & 2.65 & 2.151 & .033 \\
\hline
\end{tabular}

Note: Higher mean score equals greater level professional activity. The scale ranges from $4=$ most frequently, $3=$ frequently, $2=$ less frequently, $1=$ not at all.

the data showed that on average those who were qualified up to a bachelor degree $(M=2.66)$ used Facebook more than those who had a master degree or above $(\mathrm{M}=2.33)$, $(t=3.251, p=.001)$. Finally, the results related to the activity of sharing news on Facebook indicated that on average those who were qualified up to a bachelor degree $(\mathrm{M}=2.89)$ used Facebook more than those journalists who studied master degree or above $(\mathrm{M}=2.74),(\mathrm{t}=1.720$, $\mathrm{p}=.086)$. Thus, it was deduced that subject to educational qualification overall those journalists who were educated up to bachelor degree used Facebook more for all news and information activities mentioned above.

Data in Table 7 presents findings related to journalists' Facebook usage for news and information and their native language. In this way, first, about finding news and information on Facebook it revealed that on average those who spoke Sindhi $(M=3.16)$ used Facebook more than those who spoke Urdu $(\mathrm{M}=2.88),(\mathrm{t}=2.647, \mathrm{p}=.015)$. Similarly second, in the context of getting news story ideas from Facebook information the data showed that on average those who spoke Sindhi $(M=2.96)$ used Facebook more than those who spoke Urdu $(M=2.65),(t=2.839$, $\mathrm{p}=.005)$. Third, in the context of following news stories shared on Facebook, the data showed that on average those who spoke Sindhi $(M=2.65)$ used Facebook more than those who spoke Urdu $(\mathrm{M}=2.45),(\mathrm{t}=1.982, \mathrm{p}=.048)$. Fourth, in the context of saving Facebook information the data showed that on average those who spoke Sindhi $(M=2.63)$ used Facebook more than those who spoke Urdu ( $M=2.15),(t=4.367, p=.000)$. Finally, the results related to the activity of sharing news on Facebook indicated that on average those who spoke Sindhi $(M=2.88)$ used Facebook more than those who spoke Urdu $(\mathrm{M}=2.65),(\mathrm{t}=2.151, \mathrm{p}=.033)$. Therefore, it concluded that in the context of mother language those journalists who spoke Sindhi language used Facebook more for all news and information activities said before.

\subsection{Facebook usage for News and Information and Work Profile of the Journalists}

Data in Table 8 presents findings related to journalists' Facebook usage activities for 'news and information' and job type of the news-workers. First, regarding the activity of searching news and information on Facebook it revealed that on average those journalists who worked for news editing job category $(M=3.17)$ comparatively used Facebook more than those who reported news $(M=2.87)$, $(\mathrm{t}=2.880, \mathrm{p}=.004)$. Similarly second, in the context of getting news story ideas from Facebook information the data showed that on average those journalists who worked for news editing job category $(\mathrm{M}=2.86)$ comparatively used Facebook more than those who worked for news reporting $(\mathrm{M}=2.80),(\mathrm{t}=.579, \mathrm{p}=.563)$. Third, in the context of following news stories shared on Facebook the data showed that on average those who worked for news editing job category $(M=2.61)$ used Facebook more than those who worked for news reporting $(\mathrm{M}=2.50),(\mathrm{t}=1.054, \mathrm{p}=.293)$. Fourth, in the context of saving Facebook information, the data showed that on average those who worked for news editing job category $(\mathrm{M}=2.52)$ used Facebook more than those who worked for news reporting $(M=2.44)$, $(\mathrm{t}=.708, \mathrm{p}=.479)$. Finally, the results related to the activity of sharing news on Facebook indicated that on average those who worked for news editing job category $(\mathrm{M}=2.83)$ used Facebook more than those who worked for news reporting $(\mathrm{M}=2.81),(\mathrm{t}=.150, \mathrm{p}=.881)$. Therefore, overall it concluded that in the context of job type those who edited news used Facebook more than those jour- 
Table 8. Facebook usage activities for news and information and job type

\begin{tabular}{|l|l|l|l|l|}
\hline \multirow{2}{*}{$\begin{array}{l}\text { Facebook usage activities for news and } \\
\text { information }\end{array}$} & Job type & \multirow{2}{*}{ T-test } & \multirow{2}{*}{ P-value } \\
\cline { 2 - 5 } & News editing Mean & News reporting Mean & & 2.880 \\
\hline Finding news and information on Facebook & 3.17 & 2.87 & .004 \\
\hline Getting news story ideas from Facebook & 2.86 & 2.80 & .579 & .563 \\
\hline Following story shared on Facebook & 2.61 & 2.50 & 1.054 & .293 \\
\hline Saving Facebook news and information & 2.52 & 2.44 & .708 & .479 \\
\hline Sharing news and information on Facebook & 2.83 & 2.81 & .150 & .881 \\
\hline
\end{tabular}

Note: Higher mean score equals greater level professional activity. The scale ranges from $4=$ 'most frequently', $3=$ frequently, $2=$ less frequently, 1 = 'not at all'.

nalists who worked for news reporting for all news and information activities mentioned above.

Data in Table 9 presents findings related to journalists' Facebook usage activities for news and information and the working city of the news-workers. In this way, first, about the activity of finding news and information on Facebook it revealed that on average those journalists who were employed in Karachi $(\mathrm{M}=3.08)$ used Facebook more than those who worked in Hyderabad $(\mathrm{M}=3.07)$, $(\mathrm{t}=-.041, \mathrm{p}=.967)$. Similarly, second, in the context of getting news story ideas from Facebook information the data showed that on average those who worked in Karachi $(M=2.94)$ comparatively used Facebook more than those journalists who were employed in Hyderabad $(\mathrm{M}=2.78)$, $(\mathrm{t}=-1.632, \mathrm{p}=.104)$. Third, in the context of following news stories shared on Facebook the data showed that on average those who worked in Karachi city $(M=2.71)$ comparatively used Facebook more than those who were employed in Hyderabad for news reporting $(\mathrm{M}=2.44)$, $(\mathrm{t}-2.747, \mathrm{p}=.006)$. Fourth, in the perspective of saving Facebook information, the data showed that on average those journalists who were employed in Karachi $(\mathrm{M}=2.59)$ comparatively used Facebook more than those who were employed in Hyderabad ( $\mathrm{M}=2.37),(\mathrm{t}=-2.090, \mathrm{p}=.037)$.
Finally, the results related to the activity of sharing news on Facebook indicated that on average those who worked in Karachi $(\mathrm{M}=2.87)$ used Facebook more than those who worked in Hyderabad $(\mathrm{M}=2.74),(\mathrm{t}=-1.460, \mathrm{p}=.145)$. Therefore, overall it concluded that in the regard of working city those journalists who worked in Karachi used Facebook more than those who worked in Hyderabad for all news and information activities mentioned above.

\section{Conclusion}

This study focused on how journalists of urban areas in Pakistan use Facebook for professional activities. Hence, a cross-sectional survey was done to collect by using a pre-designed close-ended questionnaire. The targeted population of this study was urban journalists residing in the precincts of Karachi Division and Hyderabad District in Sindh province. For sample selection purposive sampling technique was applied as the complete inventory of the all working journalists was unavailable to the researcher. Thus, the analyzed data showed that the typical surveyed journalist was male and married belonging with the age group between 25 to 40 years old. Moreover, the typical surveyed journalist spoke Sindhi language

Table 9. Facebook usage activities for news and information and working city

\begin{tabular}{|c|c|c|c|c|}
\hline \multirow{2}{*}{$\begin{array}{l}\text { Facebook usage activities for news and } \\
\text { information }\end{array}$} & \multicolumn{2}{|l|}{ Working city } & \multirow{2}{*}{ T-test } & \multirow{2}{*}{$P$ value } \\
\hline & Hyderabad Mean & Karachi Mean & & \\
\hline Finding news and information on Facebook & 3.07 & 3.08 & -.041 & .967 \\
\hline Getting news story ideas from Facebook & 2.78 & 2.94 & -1.632 & .104 \\
\hline Following stories shared on Facebook & 2.44 & 2.71 & -2.747 & .006 \\
\hline Saving Facebook news and information & 2.37 & 2.59 & -2.090 & .037 \\
\hline Sharing news and information on Facebook & 2.74 & 2.87 & -1.460 & .145 \\
\hline
\end{tabular}

Note: Higher mean score equals greater level professional activity. The scale ranges from $4=$ 'most frequently', $3=$ frequently, $2=$ less frequently, 1 = 'not at all'. 
and believed in Islam. Added he professionally belonged to Karachi Division. However, in the context of professional characteristics of the sampled journalist it developed that the typical surveyed journalist edited news and worked for Sindhi language media organizations particularly TV channel. Moreover, it stood that out of the total of five the most frequent three professional activities of the urban news-workers were first, finding news and information; second, getting news story ideas, and then third sharing news and information on Facebook. Finally, out of the total of six developed hypotheses the following four proved correct as described first, on average compared with married the unmarried journalists used Facebook more for professional activities; second, on average compared with old age the young age journalists used Facebook more for professional activities; third, on average compared with more educated the less educated journalists used Facebook more for professional activities; and fourth on overage journalists of Karachi Division comparatively used Facebook more than the journalists of Hyderabad District for professional activities. However, against it the remaining two hypotheses proved incorrect which are described as first, on average compared with those who spoke Urdu language the Sindhi language speaking journalists used Facebook more for professional activities; and second, compared with news reporting journalists the news editing journalists used Facebook more for professional activities.

\section{References}

1. American Journalism Review. Date accessed: 09/04/2019. https://en.wikipedia.org/wiki/American_Journalism_ Review.

2. Raymond RK, Lu Y. Reporting on the reporters: Facebook and journalists, Innovation Journalism. 2011; 8(2):3-26.

3. Arceneaux N, Weiss AS. Seems stupid until you try it: Press coverage of Twitter, 2006-9, New Media and Society. 2010; 12(8):1262-79. https://doi.org/10.1177/1461444809360773.

4. Waters RD, Tindall NTJ, Morton TS. Media catching and the journalist-public relations practitioner relationship: How social media are changing the practice of media relations, Journal of Public Relations Research. 2010; 22(3):241-64. https://doi.org/10.1080/10627261003799202.

5. Making news. Macmillan. Date accessed: 1980. https:// www. amazon.com/Making-News-Constructionpublished-Macmillan/dp/B00EKYDF9U.
6. Urista MA, Dong Q, Day KD. Explaining why young adults use MySpace and Facebook through uses and gratifications theory, Human Communication. 2009; 12(2):215-29.

7. Mendoza S. To friend or not to friend? American Journalism Review. 2008; 30(5):12-13.

8. Gulyas A. The influence of professional variables on journalist's uses and views of social media: A comparative study of Finland, Germany, Sweden and the United Kingdom, Digital Journalism. 2013; 1(2):270-85. https://doi.org/10.1 080/21670811.2012.744559.

9. Barthel M, Shearer E, Gottfried J, Mitchell A. The evolving role of news on Twitter and Facebook. Pew Research Center. 2015.

10. Ellison NB, Vitak J, Gray R, Lampe C. Cultivating social resources on social network sites: Facebook relationship maintenance behaviors and their role in social capital processes, Journal of Computer-Mediated Communication. 2014; 19(4):855-70 https://doi.org/10.1111/jcc4.12078.

11. Kümpel AS, Karnowski V, Keyling T. News sharing in social media: A review of current research on news sharing users, content, and networks, Social Media+ Society. 2015; 1(2):1-14. https://doi.org/10.1177/2056305115610141.

12. An J, Quercia D, Crowcroft J. Fragmented social media: a lookinto selective exposure to political news. In: Proceedings of the 22nd International Conference on World Wide Web; 2013. p. 51-52. https://doi.org/10.1145/2487788.2487807.

13. Morgan JS, Lampe C, Shafiq MZ. Is news sharing on Twitter ideologically biased? In: Proceedings of The 2013 Conference on Computer Supported Cooperative Work; 2013. p.887-96. https://doi.org/10.1145/2441776.2441877.

14. Bakshy E, Hofman JM, Mason WA, Watts DJ. Everyone's an influencer: Quantifying influence on twitter. In: Proceedings of the Fourth ACM International Conference on Web Search and Data Mining; 2011. p. 65-74. https:// doi.org/10.1145/1935826.1935845.

15. Bandari R, Asur S, Huberman BA. The pulse of news in social media: Forecasting popularity. In: Sixth International AAAI Conference on Weblogs and Social Media; 2012. p. $1-8$.

16. Boczkowski PJ, Mitchelstein E. How users take advantage of different forms of interactivity on online news sites: Clicking, e-mailing, and commenting, Human Communication Research. 2012; 38(1):1-22. https://doi. org/10.1111/j.1468-2958.2011.01418.x.

17. Hansen A, Cottle S, Newbold C, Negrine R. Mass communication research methods. NYU Press; 1998. p. 350. https://doi.org/10.1007/978-1-349-26485-8.

18. Singleton RA, Straits BC, Straits M. Approaches to Social Research: Oxford University Press. New York and Oxford; 1999. 